Portland State University

PDXScholar

4-1-2021

\title{
COVID-19 Exacerbates Existing System Factors That Disadvantage Defendants: Findings from a National Survey of Defense Attorneys
}

Tarika Daftary-Kapur

Montclair State University

Kelsey S. Henderson

Portland State University, kelsey.henderson@pdx.edu

Tina M. Zottoli

Montclair State University.

Follow this and additional works at: https://pdxscholar.library.pdx.edu/ccj_fac

Part of the Criminology Commons

Let us know how access to this document benefits you.

\section{Citation Details}

Daftary-Kapur, Tarika; Henderson, Kelsey S.; and Zottoli, Tina M., "COVID-19 Exacerbates Existing System Factors That Disadvantage Defendants: Findings from a National Survey of Defense Attorneys" (2021). Criminology and Criminal Justice Faculty Publications and Presentations. 98.

https://pdxscholar.library.pdx.edu/ccj_fac/98

This Post-Print is brought to you for free and open access. It has been accepted for inclusion in Criminology and Criminal Justice Faculty Publications and Presentations by an authorized administrator of PDXScholar. Please contact us if we can make this document more accessible: pdxscholar@pdx.edu. 
(C) 2021, American Psychological Association. This paper is not the copy of record and may not exactly replicate the final, authoritative version of the article. Please do not copy or cite without authors' permission. The final article will be available, upon publication, via its DOI:

$10.1037 / \mathrm{lhb} 0000442$

\title{
COVID-19 exacerbates existing system factors that disadvantage defendants: Findings from a national survey of defense attorneys
}

\author{
Tarika Daftary-Kapur ${ }^{1}$, Kelsey S. Henderson ${ }^{2}$, and Tina M Zottoli ${ }^{3}$ \\ ${ }^{1}$ Department of Justice Studies, Montclair State University \\ ${ }^{2}$ Department of Criminology and Criminal Justice, Portland State University \\ ${ }^{3}$ Department of Psychology, Montclair State University
}

\begin{abstract}
Author Note
Tarika Daftary-Kapur https://orcid.org/0000-0002-9157-12164

Kelsey S. Henderson https://orcid.org/0000-0002-9216-1842

Tina M. Zottoli https://orcid.org/0000-0002-3197-935X

We have no conflicts of interests to disclose.

We would like to acknowledge two research assistants who worked on this project, Brandon Shintani and Zoe Ferguson.

Correspondence concerning this article should be addressed to Tarika Daftary-Kapur, 1 Normal Avenue, Montclair, NJ 07043, daftarykaput@montclair.edu
\end{abstract}




\begin{abstract}
Objective: COVID-19 has impacted many facets of daily life and the legal system is no exception. Legal scholars have hypothesized that the effects of the pandemic may contribute to more coercive plea bargains (Cannon, 2020; Johnson, 2020). In this study, we explored defense attorneys' perceptions of whether and how the plea process has changed during the COVID-19 pandemic.

Hypotheses: This study was exploratory, and we made no a priori hypotheses.

Method: We surveyed 93 practicing United States defense attorneys about their perceptions of whether and how the pandemic has affected court procedures, plea-bargaining and prosecutorial behavior, and defendant decision-making. We conducted semi-structured follow-up interviews with 13 defense attorneys to help contextualize the survey responses.

Results: The majority of defense attorneys reported $(81 \%, n=76)$ that the plea process had changed during the COVID-19 pandemic, and that they experienced difficulty contacting and communicating with their clients, especially those who were detained. Two thirds of defense attorneys $(n=42)$ who said the process had changed thought that prosecutors were offering more lenient deals. One third of defense attorneys with detained clients $(n=23)$ reported having had clients plead guilty due to COVID-19 related conditions who might not have under normal circumstances.

Conclusions: The majority of defense attorneys reported that the COVID-19 pandemic has impacted their ability to access and advise clients, and they believed that leverage in plea negotiations had shifted further to individual prosecutors. At the same time, the attorneys
\end{abstract}


reported that prosecutors were offering more lenient deals, painting a complex picture of the plea negotiation process during the pandemic.

Public significance statement: Our finding suggest that responses designed to mitigate the effects of CO VID-19, such as court closures and virtual hearings, may adversely impact attorney client-communication and the fairness of the plea process for defendants. Courts should closely monitor whether and how accommodations implemented to maintain safe operations might affect defendants' access to legal advice and the validity of their guilty pleas.

Keywords: plea bargaining, COVID-19, pandemic, defense attorneys, prosecutors 
The overwhelming majority of criminal convictions (estimates range between 90-97\%) are the result of guilty pleas (Devers, 2011), most of which follow some form of negotiation or concession by the state (Bibas, 2011). Despite the high frequency with which plea deals are used, most people — aside from the usual courtroom actors - understand neither the mechanics of plea bargaining nor the reasons so many people decide to plead guilty (Bibas, 2012). Over the last 15 years, legal scholars have suggested that the leveraging of charging power by prosecutors has made plea bargaining coercive, such that many defendants feel compelled to forfeit their trial rights (Caldwell, 2011; McCoy, 2005). More recently, some have raised concern that the impacts of the COVID-19 pandemic could exacerbate existing problems with the plea-bargaining process (Cannon, 2020; Johnson, 2020).

The primary response among courts during the COVID-19 pandemic has been to reduce or eliminate in-person operations. As an alternative to in-person hearings, some courts have adopted virtual or hybrid (combination of in-person and virtual) formats. Despite attempts to continue some operations virtually, court closures have created a substantial backlog of cases. Ninety-eight percent of responding jurisdictions in a recent survey reported that they had postponed or delayed court hearings (National Association of Criminal Defense Lawyers, 2020). In Connecticut, the Judicial Branch estimated that pending civil cases have increased by $31 \%$ and pending criminal cases have doubled (Stuart, 2020). The backlog in criminal cases in New York City has risen by nearly a third since February 2020, the month before all trials in the state were postponed because of the pandemic. By June 2020, the backlog had reached 39,200 cases (Feuer et al., 2020). Jury trials in almost all states were suspended starting in March through the summer, and a number of states passed emergency orders suspending the speedy trial rule (Roth, 
2020). Legal scholars caution that the resulting bottlenecks pose a heightened risk for coercive pleas not only currently, but into the future as defendants await trial dates, particularly those defendants in custody (Johnson, 2020). Remote proceedings can slow down the plea process by keeping some defendants in pretrial detention for longer periods because there are fewer opportunities for courtroom discussions and negotiations (Turner, 2020).

While courts have been implementing measures to prevent the spread of COVID-19, jails and prisons have experienced outbreaks. As of April 13 2020, the Marshall Project (2021) estimated that approximately 394,980 individuals had tested positive for COVID-19 in prisons. A recent John Hopkins study found that cases of COVID-19 were five times higher in prisons than the outside population, and the death rate was three times higher (Saloner et al., 2020). Given the revolving door of jails—10 million individuals annually—-the number of infections in jails is likely similar, if not higher, putting both individuals in the facilities and the communities they return to at risk. Moreover, problems of overcrowding, inadequate ventilation, and inability to social distance are often worse in jails than they are in prisons.

Under normal conditions, defendants may perceive pretrial detention as coercive (Euvrard \& Leclerc, 2017); indeed, jail data from 25 states revealed that defendants held in pretrial detention pleaded guilty almost three times faster than those who were released pretrial (Peterson, 2019). Fear of contracting COVID-19 while in jail may exacerbate this effect. Concerns have been raised that some prosecutors might threaten defendants by suggesting the plea is the only method of avoiding incarceration and possible exposure to COVID-19 (Johnson, 2020) and a defendant's ability to reject a guilty plea during the pandemic can be limited due to a 
lack of available options (Maher, 2020). It is plausible that as the pandemic continues, and there are COVID-19 outbreaks in jails, more defendants will be compelled to plead guilty to nonincarcerative sentences regardless of factual guilt.

COVID-19 has had other direct and indirect procedural impacts that might affect the plea process. Among these are the restrictions that jails and prisons have placed on in-person meetings between attorneys and their clients (Johnson, 2020). Meaningful dialogue with counsel is necessary for defendants to voluntarily and knowingly waive the right to trial. Scholars have highlighted concerns related to access to counsel and use of virtual conferencing (Johnson, 2020), including restricted time limits for virtual meetings as well as security risks posed by some of the technology platforms in use (Baldwin et al., 2020). This limited communication may ultimately impact the quality of representation by restricting an attorney's ability to build a relationship with their client and to understand their client's perspective on case facts (Johnson, 2020). Pandemic plea agreements might also include waivers of rights that were not included before, such as waiving the right to a compassionate release request, right to a sentencing reduction if the guidelines decrease, and right to seek early termination of supervised release (Johnson, 2020).

In sum, several authors have discussed how the COVID-19 pandemic may either directly (i.e., jail and prison outbreaks) or indirectly (i.e., via procedural changes implemented by the criminal justice system to mitigate against its spread) affect criminal justice system outcomes (Baldwin et al., 2020; Cannon, 2020; Johnson, 2020). Two possible outcomes of suspended or delayed jury trials are that prosecutors will offer more attractive pleas to close cases and reduce jail populations; or prosecutors will play hardball and refuse to negotiate as the defendant's only 
option to resolve a case in the short-term is to accept a plea offer. Although some of these effects might benefit defendants (e.g., as cases become stale, they are more difficult to prosecute; Johnson, 2020), there is greater concern that these impacts will be harmful to the plea process (Cannon, 2020; Turner, 2020).

\section{Current Study}

Despite concerns that the pandemic could increase coercion in plea bargaining, we do not know of a concerted effort to reach defense attorneys to survey them about their experiences with plea bargaining during the pandemic. To address this gap, we surveyed practicing United States defense attorneys about their perceptions of whether and how the pandemic has affected court procedures (e.g., suspension of speedy trial), plea-bargaining and prosecutorial behavior (e.g., changes in plea offers), and defendant decision-making (e.g., voluntariness of the guilty plea). We conducted brief semistructured interviews with a subgroup of the responding attorneys to further contextualize the survey responses. Our goal was to highlight some of the challenges, adaptations, and concerns of attorneys bargaining in the shadow of the virus (Maher, 2020).

\section{Method}

\section{Participants and Recruitment}

We recruited U.S. defense attorneys via advertisements posted on the LinkedIn and Twitter social media platforms. In addition, we sent email solicitations to two organizations with whom the we had established relationships in New York and Oregon, and disseminated the research opportunity on the Indigent Defense Research Association listserv. Any U.S. defense attorney who had represented at least one client since the start of the pandemic (defined as March 1, 2020) was eligible to participate. 
Over a 3-week recruitment period, 93 attorneys responded from 19 different states (See Table 1 for states represented). Sixty percent of the attorneys identified as public defenders ( $n=$ $56), 6.5 \%$ as assigned counsel $(n=6), 17 \%$ as private defense attorneys ( $n=16)$, and $4 \%$ as juvenile defense attorneys $(n=4) ; 12 \%$ preferred not to respond $(n=11)$. Ninety-five percent practiced primarily in criminal court, and 5\% in juvenile court. Although this was a small sample, the percentage of public defenders was representative of practice nationwide. Approximately $66 \%$ of all defense attorneys in the United States are public defenders (McGough, 2011). We collected no other demographic information

At the end of the online survey, we asked respondents to indicate whether they would be willing to participate in a follow-up phone interview. Forty-one attorneys (44\%) indicated interest; and we conducted semi-structured interviews with 13 attorneys. ${ }^{1}$ The follow-up interviews took roughly 20 minutes, on average, and we compensated participants with $\$ 25$ for their time. We have included the online survey as supplemental online material.

\section{Online Survey}

We designed our quantitative survey items to capture information related to perceived changes in court processes during the pandemic (e.g., "Has the plea process changed for you during the COVID-19 pandemic?"), changes in prosecutorial behavior during COVID-19 (e.g., "Prosecutors are dismissing cases at a greater rate during COVID-19"), and the impact of COVID-19 on defendant decision making (e.g., "My clients are feeling pressured to plead guilty because of COVID-19"). We also incorporated four open-ended questions to provide attorneys an opportunity to elaborate on their survey item responses, and to provide us with additional

\footnotetext{
${ }^{1}$ We sent interview invites to all 41 attorneys who indicated an interest in the follow-up interviews. Three interview invites were sent out over a course of 3 weeks, and 13 individuals responded.
} 
information on the impacts of COVID-19 that we did not contemplate when designing our survey.

\section{Court Procedures and Related Processes}

We asked attorneys how court procedures in their jurisdiction had been impacted by the pandemic, specifically if in person hearings had halted (yes, no). We also asked whether their ability to communicate with their clients had been impacted by the pandemic. Attorneys were asked to indicate their agreement on three measures on a $0-100 \%$ sliding scale, with the starting point centered, ranging from 0 (strongly disagree) to 100 (strongly agree): (a) My ability to communicate effectively with my clients has been impacted by COVID-19; (b) My access to clients has been impacted as a result of COVID-19; and (c) I have changed how I am advising my clients during the COVID-19 pandemic. If applicable, attorneys were asked to describe how 'remote' meetings have changed their level of engagement with their clients (open-field).

\section{Impact of COVID-19 on Plea Bargaining and Prosecutorial Behavior}

We asked all attorneys if, in their opinion, the plea process had changed during the pandemic (yes, no), and if so, to describe the specific changes in an open-field response box. Attorneys were also asked whether prosecutorial behavior in plea negotiations had changed. Unfortunately, due to a glitch in the survey, only attorneys who indicated that they had had at least one detained client during the pandemic received the questions related to prosecutorial behavior ( $\mathrm{n}=68$; we address implications of the data loss in the Discussion section). Specifically, we asked these attorneys to rate their level of agreement with three statements: (a) Prosecutors are dismissing cases at a greater rate during COVID-19; (b) Prosecutors are utilizing pretrial detention less frequently during COVID-19; and (c) Prosecutors are offering more 
lenient (e.g., nonincarcerative) deals during COVID-19. Attorneys answered these questions using a $0 \%-100 \%$ sliding scale, with the starting point centered, ranging from 0 (strongly disagree) to 100 (strongly agree).

We asked defense attorneys if they had seen any language added to plea agreements that would preclude clients from trying to appeal their conviction on the grounds that they felt pressure to plead during the pandemic (yes, no). And at the end of the survey, attorneys were asked if there was anything more they wished to share about how the plea process, as they have experienced it, has been impacted by COVID-19 (open-field).

\section{Defendant Decision Making}

We asked attorneys if they have had a client plead guilty or indicate a willingness to plead guilty because of the fear of contracting COVID-19 in jail (yes, no). On a $0 \%-100 \%$ sliding scale, with the starting point centered, ranging from 0 (strongly disagree) to 100 (strongly agree), attorneys indicated their agreement with statements assessing whether their clients were feeling pressured to plead guilty due to COVID-19 related issues: (a) My clients are feeling pressured to plead guilty because of COVID-19; and (b) COVID-19 is not a factor used by my detained clients in their decisions to accept/reject a plea offer. Attorneys then estimated the percentage of their clients who have given any of the following reasons as justification for accepting a plea offer: (a) get out of jail because of the fear of contracting COVID-19, (b) save money, (c) return to their job, (d) resolve the matter quickly, (e) have fewer or less serious offenses on their record, and (f) family obligations. Finally, we asked respondents if any of their clients had made claims of innocence but agreed to a nonincarcerative plea deal due to fear of contracting COVID-19 (yes, no); and if so, to explain (open-field). 


\section{Materials: Defense Attorney Interviews}

We focused our defense attorney interviews on three themes explored in the survey- the impact of COVID-19 on court procedures and related processes; the impact of COVID-19 on plea bargaining and prosecutorial behavior; and the impact of COVID-19 on defendant decision making. Follow-up questions gave attorneys the opportunity to elaborate on their survey responses and enabled us to probe for more details. We did not ask every attorney the follow-up questions if their initial response addressed all aspects of our inquiry. The main questions with follow-up questions denoted in italics were:

1. Have there been any procedural changes (e.g., access to confidential meetings with clients, court dates pushed back, and changes in judicial involvement) or policy changes that have affected bargaining or decision-making as a result of the COVID-19 pandemic? If so, please provide an example? In some jurisdictions speedy trial has been suspended. Is that the case in your jurisdiction? What do you think the impact of this will be?

2. How has COVID-19 impacted bargaining and plea offers? If so/Example? That is, are prosecutors offering different offers than you would have typically seen for certain charges (pre-pandemic)? If so/Example? Have you seen any changes in prosecutorial dismissals? If so/Example?

3. Do you think the pandemic has impacted the voluntariness of guilty pleas? If so/Example? Do you think defendants are feeling an increased pressure to accept pleas during the pandemic? If so/Example? Have you seen any different waivers 
included in plea agreements? Has the lack of jury trials (or virtual option)

impacted defendants' plea decisions? If so/Example?

We transcribed all 13 recorded interviews verbatim and the two lead authors independently coded the interview transcripts. Interrater reliability (Cohen's kappa) between coders was .89. Twenty-one distinct codes emerged from the coding. Disagreements were resolved through discussion and consensus between the two lead authors.

\section{Procedure}

The Montclair State University Institutional Review Board approved all procedures and materials prior to data collection (IRB-FY19-20-1857). Because this project utilized a mixed method approach, there were two distinct components: (a) survey questionnaire that was disseminated through various online avenues, and (b) semistructured interviews with a subsample of the survey sample who indicated they would be willing to participate.

\section{Online Survey}

Solicitations described the purpose of the study, that participation was voluntary and anonymous, and provided the Qualtrics survey link. Participants first read the Informed Consent document, then answered the survey questionnaire. The average time to complete the survey was 10 minutes, ranging from 7 to 18 minutes. At the end of the survey, respondents indicated if they would be willing to participate in a 15-20 min phone interview on changes in the plea negotiation process during COVID-19. Participant contact information for the phone interviews was detached from survey responses to ensure anonymity.

\section{Defense Attorney Interviews}


We emailed a signup link to defense attorneys who expressed willingness to participate in the follow-up interview. Interviews took place via Google Meets and Zoom. All participants listened to an Informed Consent script and, after verbally indicating consent, they completed the interview protocol. Interviews took an average of 20 minutes, ranging from 13 to 28 minutes. Participants received \$25 via Venmo or Paypal in exchange their participation. Three attorneys declined the honorarium.

\section{Results}

We surveyed and interviewed defense attorneys about their perceptions of whether and how the pandemic has affected court procedures, plea-bargaining and prosecutorial behavior, and defendant decision-making. We present the results accordingly. We supplement the survey data with additional context that came from the 13 follow-up interviews. We selected participant quotes that were representative of the overall tone and content of all statements in each specific category. See Table 2 for quantitative results from the survey and Table 3 for a summary of categories, percentage referenced, and example responses from the qualitative interviews. All open-ended responses from the survey, scrubbed for identifiers, are included as online supplemental material.

\section{Theme 1: Impact of COVID-19 on Court Procedures and Related Processes}

The majority of attorneys in our sample $(83 \% ; n=78)$ answered "yes" when asked if in-person hearings had halted, at least partially during the pandemic, in their jurisdiction and $81 \%(n=76)$, answered "yes" when asked if the plea process had changed. In this section we describe attorneys' perspectives on how these changes have affected their access to and 
communication with clients as well as issues they raised about deficiencies in virtual trials and hearings.

\section{Client Access and Quality of Communication}

We asked all participants to rate their level of agreement, on a sliding scale, ranging from 0 (strongly disagree) to 100 (strongly agree), with the starting point centered, on three statements related to changes in client access and communication. Disagreement was operationalized as ratings of $0-49$, and agreement as $51-100$ on the sliding scale. As displayed in Table 2, 86\% of the attorneys $(n=80)$ agreed with the statement that their ability to communicate effectively with their clients had been impacted by COVID-19 $(M=81.55, S D=28.84$, Mode $=100) ; 87 \%$ of the attorneys $(n=82)$ agreed with the statement that their access to clients had been impacted by COVID-19 $(M=84.12, S D=26.62$, Mode $=100)$; and $83 \%(n=77)$ agreed with the statement that they have changed how they advise their clients during the COVID-19 pandemic $(M=64.56, S D=33.05$, Mode $=100)$.

Next, we asked attorneys "If applicable, please describe how remote meetings have changed your level of engagement with your clients." Responses clustered in three related areas: communication issues, technological barriers, and restricted access to detained clients. Attorneys $(29 \% ; n=28)$ described difficulties related to communication with their clients. For example:

"[I]t has made contact and communication much more difficult. My clients feel disconnected from me in a way that creates unease and confusion."- Survey respondent \#27

"For most of my clients, it hasn't been a bad thing, [but clients] that are special needs due to mental health issues, homelessness, drug addiction, etc., have been negatively impacted. My special-needs clients need more handholding than I can provide remotely."- Survey respondent \#44

"It has been really challenging to build trusting relationships with clients, especially those who suffer from mental illness. [I have] had an increase in clients feeling angry and ill-informed. I now have clients calling/texting me constantly because they are experiencing so much instability and I am their only point of contact."- Survey respondent \#65 
Technological barriers, both in the form of clients accessing web platforms they had little experience with (e.g., Zoom) and a lack of access to devices (e.g., phones and computers), was also a common theme in these responses, mentioned by $29 \%$ of attorneys $(n=27)$.

"[It's] harder to assess a client's demeanor, which is relevant in assessing trial potential. Harder to get in touch with indigent clients who are more likely to have no phone, or phones that don't always work. Harder to get paperwork which is needed for cases."- Survey respondent \#26

"Many of our clients are difficult to track down but would often show up for in person hearings. When in person I could use a few minutes before court to meet with them and make a game plan. Now I don't always have that opportunity and I can't tell the court why I have no updates."Survey respondent \#42

Finally, $64.5 \%$ of attorneys $(n=60)$, which reflects $88 \%$ of all those who had represented a detained client $(n=68)$, agreed that that access to their clients had been impacted (e.g., attorneys not allowed in the jail). These views were also reflected in open-ended responses when asked about the impact of remote meetings. Twenty percent $(n=18)$ of attorneys expressed views that the alternatives to in-person meetings had made it harder to develop the quality of relationship with clients that contributes to effective representation.

"We have no real bond via remote meetings. There is no basic trust or relationship that happens in person. Plus, the jail utilizes a software program that doesn't work more often than it does work, so it is nearly impossible to get a client meeting. When we do get [a meeting], there might be no video, or no audio, or other detained people [are] in the same room, or guards [are] walking in/out, and the phones are not cleaned in between uses, increasing the spread of COVID [...]. Visits are limited to 15 or 30 minutes, but rarely last that long. I have no meaningful relationships with clients in custody. They don't trust me because they've never even met me in person [...] They are all terrified and think I should be able to help more than I am able to do."- Survey respondent \#93

"Clients are forced to make decisions to plead guilty having never seen my face, only [hearing] my voice on phone calls because Federal prosecutors insist on plea cutoff dates even in the pandemic. Some clients I can zoom with, but I can rarely have enough time on zoom even with screen sharing to review all discovery at once. If I don't have zoom capabilities, the client can't see video evidence because they aren't allowed to go to the library to see it"- Survey respondent $\# 13$ 
Attorneys representing non-English speaking clients may perceive these impacts as more problematic. A small number $(4 \%, n=4)$ of these attorneys mentioned that COVID-19 has presented barriers to securing access to interpreters (this issue came up when we asked, "Do you wish to share more about how the plea process, as you have experienced it, has been affected by COVID-19? If so, please respond below)", for example:

"Communication with incarcerated non-English speaking clients is very problematic. Until approximately mid-June, I was unable to find an interpreter willing to meet with me at the jail. The local jail allowed me to set up a three-way phone call with client/interpreter but client was not able to speak privately."- Survey respondent \#53

A minority of attorneys surveyed also expressed concerns about the security and confidentiality of virtual meetings with detained clients, including whether they or their clients felt comfortable engaging in meaningful discussions regarding case details and options $(11 \%, n=$ 11).

"Seeing [clients] on video is [...] not private and documents/discovery/videos cannot be shared."Survey respondent \#85

Although we explored issues related to client access and communication in our follow-up interviews, we gleaned very little new information. Responses largely mirrored the data that the attorneys provided in their open-ended response to the survey. For example:

"I work at the public defender's office. My clients are indigent. The fact that all of them have to have somehow access to a smartphone or a computer because they have to appear via Zoom or- I mean, a lot of judges will give them the option to appear in person but those dates are so scattered it's like once every two weeks or something. [...] I think that's a huge stress that is facing a lot of clients especially the indigent ones or even elderly, who don't know how to use a cell phone or how to download the app. A lot of my job is basically [...] teaching them how to set up an email address, how to download an app."- Interview \#10

\section{Virtual Proceedings and Constitutional Issues}

Although we did not explicitly ask questions on our survey about how the pandemic might impact procedural and due-process rights, a few attorneys $(4 \%, n=4)$ raised concerns 
about these protections in open-ended questions. For example, when asked if there was anything

else they would like to share regarding plea-bargaining during COVID-19, one attorney

commented:

"Covid has not impacted the plea process. However, Covid has had a serious impact on jury trials. Older jurors are less willing to sit on a jury. Juries are not a representative demographic of the defendant's peers. Wearing a mask makes it difficult for a jury to accurately tell when a witness is not being truthful. Juries do not have the ability to see the defendant's entire face. Juries are uncomfortable being on a jury for long periods of time, and are nervous about Covid. The juries just want to leave and are mentally distracted."- Survey respondent \#32

This theme also emerged in our follow-up interviews, even though we did not include a

direct question. Five attorneys ( 2 of whom alluded to this issue on their survey responses)

explicitly referenced potential procedural rights or constitutional violations involving virtual

proceedings. For example:

“[...] Speedy trial concerns, confrontation concerns. I absolutely see how that could usher someone closer to saying 'If I don't feel like I can get a fair trial than I need [to] enter a plea.' [S]ome of my more sophisticated clients have been very concerned about whether or not they're going to get a fair cross-section of the community when it comes time to go to trial, because the pandemic has disproportionately affected black and brown people. [...] some of my clients expressed concern that if they go to trial they will get nothing but people who think the pandemic is fake. [That could] make someone more likely to enter plea"- Interview \#2

"Our jail is notorious for being the worst jail in [state], but [...] if your client wants to appear in court, they will be quarantined for 21 days. So in the hole for 21 days. They have to make a decision if they want to appear in court for an important hearing or not; make a choice between not appearing or being in solitary confinement. I had a client [...] He's very young, 18. [...] He said he didn't want to go to the hearing because he doesn't want to be quarantined. [...] So, it's very difficult to have an [in-person] hearing. [With a virtual hearing], if you are going to talk to the client over Webex, they have to empty the courtroom and then you talk through the video and then everyone would reconvene and it is almost impossible to do. So, this policy really adds to the coerciveness because if you don't want to be in solitary you can't have a proper hearing. And in this case the judge made us sign something saying we would not ask for another in-person hearing until courts opened up. And he's been in for a while. Juvenile waived up to adult. He's been in since 16."- Interview \#1

\section{Theme 2: Impact of COVID-19 on Plea Bargaining and Prosecutorial Behavior}


Given the limited number or complete suspension of jury trials in most jurisdictions during the pandemic, we examined whether defense attorneys thought there had been any shifts in the nature of plea offers. We asked respondents whether the plea process had changed for them during the pandemic; $81 \%,(n=76)$ indicated that it had. We asked these attorneys to describe how the plea process had changed (open-ended question). We then asked attorneys to rate their level of agreement, from 0 (strongly disagree) to 100 (strongly agree) with three statements about prosecutorial behavior relating to plea offers, case dismissals and use of detention during the pandemic. Due to an error in the survey skip logic, only attorneys who indicated they had represented at least one detained client during the pandemic $(n=68)$ received these three questions.

\section{Dismissals}

Forty-eight percent $(n=33 ; M=34.82, S D=33.62$, Mode $=0)$ of attorneys with a detained client agreed (as reflected by a score of 51 or above on the $0-100$ sliding scale) with the statement "Prosecutors are dismissing cases at a greater rate during COVID-19." This rating suggests substantial variability across attorneys and the open-ended responses provide some context for understanding this result. For example, dismissals may be down overall in some offices because arrests have fallen for some low-level offenses and/or prosecutors have declined to bring charges for these offenses in the first place. Attorneys also noted charge-class differences in rates of dismissals and referenced individual differences in prosecutors, as Survey Respondent \#22 noted, "Some DAs have been more willing to negotiate/dismiss due to backlogs from COVID. Others have not changed at all.” Finally, changes in leverage (discussed shortly) may have led to plea offers in cases that previously might be have been dismissed. 
"Lots of formerly 'triable' low level felony cases are now receiving much better misdemeanor offers with guarantees of probation. Due to the inability to conduct jury trials over at least an 8 month period and the resulting stack up of higher level cases, low level felonies can no longer be economically and reasonably tried."- Survey respondent \#29

Given the range of responses provided on the survey, we explored this issue in greater depth in our interviews. Generally, attorneys reported that prosecutions had declined for misdemeanors (with the exception of domestic violence), but there had been no change in felony cases. Misdemeanors were the cases most likely to be dismissed or downgraded to citations.

"Lots of dismissals in the misdemeanor range, particularly. [...] A lot of [very low level misdemeanors] were getting dismissals even before the court date. The DA is just thinking this isn't even worth the time."- Interview \#9

On the other hand, a few attorneys mentioned that in their jurisdiction, prosecution of

misdemeanor cases was delayed due to the pandemic, and these cases would be prosecuted at a later to-be-determined date.

“[...] It seems like that's all they're charging [violence misdemeanor cases], I've heard that maybe- that they're waiting to charge a lot of things, you know they've given people summons of when to come to court but we don't have that information yet. We've heard that, I've heard that there's some stockpile- I don't know when it's gonna- when they're gonna whip it out but that's one huge charge."- Interview \#10

“[...] What our DA's are saying is that they aren't currently charging the misdemeanors that are coming in, but they are pending them, so the misdemeanor theft you got arrested for back in May will still come back to bite the defendant sometime in the future, which is really antagonistic to, if we claim to be doing restorative justice, how we should be dealing with these things very proactively."- Interview \#13

\section{Changes in Leverage/Nature of Deals}

Sixty-two percent of defense attorneys with detained clients $(n=42$ out of $68, M=42.46$, $S D=34.10$, Mode $=0$ ) agreed that prosecutors were offering more lenient deals (e.g., non-incarcerative plea sentences) during COVID-19. However, many of the attorneys elaborated 
on the nature of plea deals in the open-ended question asking them how plea deals had changed

during the pandemic, and their responses painted a more complex picture of prosecutor behavior.

"There have been few good offers in felony matters as ADAs have no pressure with grand juries suspended to make an offer; in fact, the offers feel more punitive than ever. But we are getting better plea deals on misdemeanor cases, mainly because of the pressure the Court is putting on ADAs to resolve cases."- Survey respondent \#60

"I have always advised my clients with minor charges or sympathetic situations that they can 'play chicken' [because] their cases may not be worth prosecuting for the DAs, or that they may get a better offer in order to avoid a trial. [...] I am now simply telling my clients that the DAs are even less likely to be able to prosecute all the cases they have. I am also advising clients that if they are inclined to try to get a deal, now is a good time to get a good deal because of the pressure to resolve cases and the lack of court access.”- Survey respondent \#26

"I think that the prosecutors are making offers and accepting offers that they would not usually accept. Some cases with bad facts for the defense and little room for suppression and exclusion have been resolved with offers I would consider good for the Defendant."- Survey respondent \#41

Few defense attorneys $(4 \%, n=4)$ described that prosecutors were altogether unwilling to bargain during the pandemic. Other defense attorneys $(18 \%, n=17)$ expressed their

perception that the leverage in plea negotiations had shifted strongly in favor of the prosecutor.

"Some prosecutors don't care. They know that we don't have trial leverage anymore. Trials are backed up to 2023 in our jurisdiction, so they don't have to make us a decent offer. They are charging the maximum, and refusing to give us a decent offer in some cases. So, my client has to take a horrible offer or rot in jail for years [waiting for a trial date].”- Survey respondent \#42

"I am disgusted by how the State Attorneys are acting. Some are deliberately refusing to drop cases they cannot prove for the sole purpose of leaving the client in jail for as long as possible before having to drop the case. It is extremely unethical. Unfortunately there is little to nothing I can do about it as trial is the only way to force the State to either prove their case or drop it. Without trials there is no mechanism by which to hold the State accountable. Right now, the States have incredible power and are heavily abusing it."- Survey respondent \#24

We explored the nature of plea offers more thoroughly in our follow-up interviews with attorneys. Consistent with their survey responses, defense attorneys described a wide spectrum of experiences. In some cases, deals were better and in other cases deals were worse, and attorneys though this depended greatly on the individual prosecutor. 
Better: "Even though now we're pretty much back on schedule and have dealt with a lot of the backlog, at the district court level the offers are still better than they used to be. They aren't as good as they were right in the middle of it, but there still is there's a substantial a recognition, I think, that the potential second wave is coming and so they're definitely trying to get [cases] taken care of when possible.”- Interview \#5

Worse: "I think they are worse. [But] it varies from prosecutor to prosecutor. [...] Especially for simple possession cases. People have 5-6 simple possession charges for things that have happened over the course of a couple of weeks. [Before the lockdown]I believe they would have been misdemeanor offers [but now] prosecutors have been wanting them to plead to every charge, and get a felony conviction. And there is no leverage. [...] Six months ago I would have said fine, we will have 5 trials. No prosecutor wants to do that, so they would plead down. But, now we don't have that leverage. So, if your client doesn't want to take the offer, and you say schedule for trial, that's fine too, but - especially if your client is in jail-you will never know when that will happen."- Interview \#1

"The only thing that I would say is I get way better pleas right before trial when I have pushed the state up until a trial; when we come to trial they've actually finally looked at their case and are starting to see the issues that I've been pointing out all along they are like oh you're right I can't prove that. I mean you have to hold them over the fire and if there's no fire they're just not even making any decent offers. Like the state doesn't like have any incentive to work their cases right now."- Interview \#4

\section{Waiver of Rights}

Only three attorneys (3\%) answered "yes" to the survey question "Have you seen language added to plea agreements that would preclude your clients from trying to appeal their conviction on the grounds that they felt pressure to plea because of the fear of contracting COVID-19?"

Despite the low endorsement rate on the survey, we asked a follow-up question related to rights waivers during the follow-up interviews. Only two attorneys noted having seen any new or different waiver language included in plea agreements, and these were related to the use of virtual proceedings and not appellate rights:

"What we are starting to see are video waivers; or, for misdemeanor cases, waivers of appearance $[\ldots]$ that says your attorney may enter a plea on your behalf within this range [or] negotiate as necessary and then enter that plea and inform you of what the results are. We obviously don't do any of these where there will be [anything other than a probationary] sentence, but we have taken care of misdemeanors [this way] because of concerns about coming to the courthouse and potential COVID exposure.”- Interview \#9 


\section{Pretrial Detention}

Nearly one-third of attorneys with a detained client $(32 \% ; n=22$ out of $68, M=44.37$, $S D=36.08$, Mode $=50$ ) agreed that prosecutors were utilizing pretrial detention less frequently during the pandemic. However, as with the question about dismissals, the open-ended responses provide valuable context. The general consensus among the attorneys was that prosecutors have not been as likely to demand pretrial detention for those charged with misdemeanors (with the exception domestic violence charges), but use of detention has remained the same for felony cases.

"Federal prosecutors in New Jersey have acted like its business as usual. Judges have defaulted to detaining people instead on erring on the side of release and setting bail conditions. The federal magistrate judges have been almost universally unwilling to acknowledge that severely compromised clients will perish in jail.”- Survey respondent \#13

"Almost all prosecutors and judges do not want to hear about the fear of COVID in jails. There has been very little change in bail [..] during this pandemic."- Survey respondent \#46

Attorneys expressed their concerns about health risks for their detained clients and, as we discuss in the next section of this article, that the use of pretrial detention during the pandemic was contributing to coercion in plea bargaining. Three attorneys also described prosecutors utilizing the fears detained defendants have about contracting COVID-19 to their advantage.

"We have no known date to resume trials, so people in pretrial custody are pleading guilty just to get out of jail.... In many cases prosecutors have been making time served offers for people in jail, but simultaneously oppose defense request for bail reductions (because why not - if they plead guilty, they will get out, why not allow for due process?). The system has become much more coercive, in terms of the plea process. COVID is inside the walls of our prison and inmates are testing positive and are symptomatic. They want to get out and get home."- Survey respondent \#23

As this was a key focus of our study, we explored issues related to pretrial detention in our follow-up interviews. Little new information was gleaned, however, as responses largely 
mirrored the survey responses. Attorneys mainly elaborated on issues related to fears of

COVID-19. For example:

"I have a client, first offense, agreed to go into jail for an assessment [not offered on the outside] and then a probation sentence. Unbeknownst to us the jail had a 7 day quarantine policy, so she would have to spend 7 days before getting the assessment. She got scared [of COVID], and called her fiancé to bail her out. The judge did not like this and changed her probation sentence to an 18 month prison sentence.”- Interview \#7

Variability in the use of pretrial detention and prosecutor differences were also noted.

"I will say at the county DA's office I am at the 2-3 reasonable people who I deal with have continued to be reasonable, and those who are not have become far more unreasonable. For example, they are asking for pretrial detention in cases where two months ago they wouldn't have asked for it, just to get my clients to plead.”- Interview \#2

\section{Theme 3: Defendant Decision-Making}

One of our key research questions examined attorneys' perceptions of whether and how defendants' plea decisions were affected by COVID-19, specifically for those who were in detention. In this section, we report attorneys' perspectives on how the various procedural and other impacts of COVID-19 have affected their clients' decisions, including the client's rationales for their plea decisions. Except where explicitly noted, the results reported in this section come from a subset of attorneys who had represented detained clients during the pandemic $(n=68)$.

\section{Reasons for Pleading Guilty}

Sixty-five percent of attorneys $(n=68, M=48.78, S D=34.26$, Mode $=20)$ agreed with the statement, "My clients are feeling pressured to plead guilty because of COVID-19," as indicated by a score of 51 or higher on the scale ranging from 0 (strongly disagree) to 100 (strongly agree). We asked attorneys to estimate the percentage of their detained clients who expressed one or more of six possible motivations for pleading guilty. On average, defense 
attorneys estimated that $60 \%$ of their clients pleaded guilty to resolve the matter quickly; $45 \%$ wanted to return to their jobs; $47 \%$ referenced family-related obligations; $42 \%$ wanted to reduce the severity of the charges on their record; $26 \%$ wanted to get out of jail because of the fear of contracting COVID-19; and 20\% pleaded guilty to save money (e.g., legal expenses). Of course, readers should be mindful that we do not know how many detained clients each of these attorneys represented or whether attorneys' perceptions were accurate.

Open-ended questions (one querying changes during the pandemic on the plea process and a final question asking attorneys for additional information they thought was relevant to the process) provided additional context, with responses about plea decisions clustering into two categories: impact of pretrial detention and impact of case backlogs.

Impact of Pretrial Detention on Decisions. Thirty-four percent of attorneys with a detained client ( $n=23$ out of 68$)$, when asked directly, reported having at least one detained client who they thought pleaded guilty (or was willing to plead guilty) specifically because of fear of contracting COVID-19 in jail. This was elaborated on in open-ended responses:

"Clients have family and friends they are especially worried about because of Covid-19, making them more willing to plea to get out. Some clients' concerns regarding Covid-19 in the jails makes them more willing to plea to get out."- Survey respondent \#29

We explored this issue further in our follow-up interviews. Client concerns about catching COVID-19 in jail on their plea decisions was a dominant theme in eight of $13(62 \%)$ of attorney follow-up interviews.

"My clients who are in jail, who already have health conditions going on have mentioned to me a real discomfort with [being in] custody and an increased willingness to do whatever it takes to get out. Granted, that's a segment of the population that is already more likely to say that, even when there's no pandemic going on. That they simply can't be [in jail] and they have to get out. But I have had probably three or four older clients, especially, mention to me that they are especially concerned [about COVID because they have] respiratory symptoms or HIV or other things like that and I feel that they especially have to get out of jail quicker.”- Interview \#6 
"It has affected the clients. [Y]ou can plead to get out of custody or you can sit in custody and wait for who knows how long. I have one trial, where we have put up an alibi defense and the client has been waiting for his "speedy trial," which in [state] is usually a 90-day demand. [H]e has been waiting since February [2020; this interview was conducted in October], and there is no end in sight. [Another] trial was set for this Monday — so just a couple of days ago — and it got preempted because, of course, it is not the only one [scheduled]. So, it got preempted by another "speedy trial," and mine got bumped to November $19^{\text {th }}$. And now my guy has been in custody since February, and all I can offer him is that if you want to get out of custody we can try and create some sort of plea deal. He is holding firm, but I can't tell you how many clients have not."Interview \#13

Likewise, almost half of our interviewees $(n=6)$ noted that some defendants who

pleaded guilty would have held out under normal conditions.

"[My clients who] would like a trial but [are] sitting in custody and can't for some reason make bail have much more of an incentive to plead. They will still probably get better offers than they would before, because the state has an incentive to move the cases, but [the clients] also have a pressure that they want to get out. If the only way they were getting out before was going to trial that is already looking like- I mean I'm jokingly [asking] prosecutors [...] are we scheduling this for 2023 or 2024?"- Interview \#9

"I mean, I wouldn't necessarily say it's not voluntary but I think it's getting pretty close to the point that they feel like there's really no other option. I mean there's these people who want to move on with their lives and apply for jobs and things like that. [...] . A lot of the times I think that if they fought it all the way through, I mean they'd get a better result."- Interview \#10

Impact of Case Backlogs (Lack of Jury Trials) on Decisions. We did not directly ask

about backlogs on our survey; nevertheless this issue was mentioned by $15 \%(n=14)$ of all 93

attorneys surveyed in response to the open-ended questions on changes in the plea process during the pandemic. Taken together, responses suggest that attorneys attributed some of the shift in defendants' willingness to plead guilty to concerns associated with the suspension or limited frequency of jury trials $(10 \%, n=9)$ or with the uncertainty in timeline for hearings and trials $(8 \%, n=7)$.

"We have no known date to resume trials, so people in pretrial custody are pleading guilty just to get out of jail.”- Survey respondent \#23

"Clients are more resigned to taking pleas because there is no clear timeline regarding when jury trials will resume, or how long it will take to work through the backlog. There are also a lot of 
unknowns regarding what trial will look like post-pandemic that some clients find concerning."Survey respondent \#29

"Individuals are more likely to plea for probation to get out of jail or to avoid more court appearances. We have to wait longer for in court hearings (especially with witnesses). Courts give the State more opportunities to get their witnesses to court. There were also delays in the department of corrections transporting inmates from county jail to DOC facilities which impacts how someone earns enhanced credits (impacting their discharge date)."- Survey respondent \#8

This theme was reiterated by attorneys during the follow-up interviews, seven of whom

talked about the significant backlog of cases in their jurisdictions. One interviewee (\#13)

indicated that trials were backlogged to 2024. Another interviewee stated:

"A lot more cases are pleading because obviously there are these big lapses between when someone's charged with something and when someone's going to get a trial. [...] The huge time difference charge and trial is really leading people to look at pleas like their only option. I think it is really suffocating to some extent."- Interview \#10

It is important to note that while attorneys most commonly discussed the effect of case backlogs with regard to detained clients, many of these same attorneys noted that their non-detained clients were also more willing to accept a guilty plea than they may have been pre-pandemic.

"And it's not just the people who are in custody. I have had clients who are saying I need to get past this, there is so much else going on that is chaotic. I need to get past this case. I don't want to keep coming into a court system where I am not feeling safe or my job situation has become so disrupted that I no longer have the ability to take the time off to come to court as required. And so yes, I absolutely $100 \%$ know that in the last 6 months I have had clients who have taken pleas just to get past this moment."- Interview \#13

\section{False Guilty Pleas}

Twenty-one attorneys (31\%) who had represented a detained client $(n=68)$, answered "yes" when asked if they had at least one client who claimed innocence, yet agreed to accept a guilty plea for a non-incarcerative sentence because of the fear of contracting COVID-19 in jail (none of the attorneys who represented non-detained clients responded in the affirmative to this 
question). Attorneys provided additional information about the pressure on innocent defendants

in response to an open-ended follow-up question ("If yes, please explain briefly"):

"Confirmed positive cases recently in my local detention center combined with social distancing/isolation type measures is making jail time harder on clients. They want out faster. They are afraid of Covid."- Survey respondent \#89

"Elderly clients with health risks just want to get out and will take anything that suspends their sentence without realizing they are prone to probation violations."- Survey respondent $\# 90$

"Clients desperately want out of jail, so are willing/wanting to plead guilty to crimes they did not commit if it means they get out of jail, or they are willing to give up very important legal challenges to unconstitutional misconduct engaged in by the police due to the uncertainty of winning a motion, and the possibility of being stuck in jail longer if they pursue their rights. It has essentially made prosecutors have even more power than they already had."- Survey respondent \#93

Responses to questions about innocence on follow-up interviews largely reflected the

themes that arose from the survey, though several $(n=6)$ of the attorneys provided some specific case examples.

"I have another person who is charged with manslaughter who is actually innocent and that person has been waiting for a year and he is getting so desperate he is telling me he wants to plead to something and I can't, you know you walk a fine line as a defense attorney between saying I can't stand up with you and say I think you should plead guilty, but my obligation is to my client and if he wants to plead guilty, I also have an obligation to stand next to him then. And he is way past his trial date, except they have suspended all the rules."- Interview \#1

"I think of one specific example who was a mental health client who said the incident didn't happen and he was held. Our jail is notorious for holding people with mental health issues even though we don't have the resources in jail. And he took a deal even though he claimed he hadn't done it, because he wanted to get out of jail because of COVID."- Interview \#7

"Absolutely, and not just people in custody. I have clients who are saying I need to get past this. I don't want to have to keep coming to court where I don't feel safe.... Or my job situation has become so disrupted [because of COVID] that I no longer have the ability to take time off to come to court. So yes, absolutely $100 \%$ I know in the last few months I have had clients take pleas just to get past this moment."- Interview \#13

\section{Discussion}


We surveyed and interviewed practicing defense attorneys across the U.S. regarding their perceptions of whether and how the COVID-19 pandemic has affected plea bargaining, in particular for detained clients. Our findings suggest that the concerns raised by legal commentators have been realized by some defense attorneys. By virtue of the geographical and jurisdictional diversity of our sample, our data also highlight variation in the impacts of the pandemic for attorneys practicing in different regions, handling different types of cases, or allocated different resources.

Two general findings emerged in our data. First, the extent to which attorneys can access and advise their clients with regard to their legal options has been substantially impacted; and second from the perspective of these attorneys, the leverage in the guilty plea negotiation process, has shifted further to the prosecutor. We examine each of these in turn, and briefly reflect on their potential impact on the validity of guilty pleas during the COVID-19 pandemic and the questions that these data pose for future research.

\section{Attorney-Client Communication}

The first major theme to emerge from our survey and interview data reflects the effect that pandemic-related procedural changes have had on attorney-client access and communication. Essential to our adversarial system is the right to effective assistance of counsel (Gideon v. Wainwright, 1963; Lafler v. Cooper, 2012; Strickland v. Washington, 1984), but consistent with the problems anticipated by legal scholars, nearly all the attorneys in our sample thought the pandemic had affected their ability to communicate with their clients. These problems included difficulty arranging meetings and providing their clients with adequate access to discovery materials, as well as various issues related to videoconferencing (e.g., 
confidentiality, building rapport, time-limits) that limited their ability to provide what they believed was effective counsel. Social-distancing protocols posed communication difficulties for attorneys representing detained clients, although getting in contact with non-detained clients was problematic as well, especially for indigent clients who might not have access to a telephone or reliable internet access. Additionally, a small number of defense attorneys noted issues with navigating communication barriers for clients who need interpreters.

Concerns over the frequency and quality of attorney-client communication existed before the pandemic (Zottoli et al., 2016). These concerns generally center on the issues of expanding caseloads, especially for public defenders (Farole \& Langton, 2010). It is well-documented that the caseloads of public defense attorneys often far exceed the standards set by the National Advisory Commission on Criminal Justice Standards and Goals (Lefstein \& Spangenberg, 2009). Attorneys who are overworked and with limited resources already face challenges communicating with clients. The technology and access challenges of the COVID-19 pandemic appear to have exacerbated these issues and raise concerns about the extent to which defendants are making knowing and intelligent plea decisions (Johnson, 2020). We turn to this topic when we discuss the implications of our data for the validity of guilty pleas.

\section{Shift in Leverage Further to the Prosecutor}

Prosecutors have an advantage in plea negotiations by virtue of their discretion to bring charges and stay sentencing. While the majority of criminal convictions in the U.S. are by guilty plea (Devers, 2011), the primary leverage held by defendants in plea negotiations is their willingness to invoke their right to trial. 
Most of the defense attorneys we surveyed indicated that the plea process had changed, though the degree and valence (from the perspective of the defendant) depended on various factors, including the nature of the charge. For instance, some attorneys indicated that prosecutors in their jurisdictions have been more willing to dismiss or plead-out misdemeanor cases for non-custodial sentences or for time-served than they had been prepandemic. Also, despite concerns that prosecutors would add additional waivers of post-conviction rights to plea agreements (Johnson, 2020), only two attorneys interviewed mentioned seeing this type of new waivers, and these were specific to appearance in court and virtual proceedings. At the same time and consistent with other concerns (Johnson, 2020; Roth, 2020), nearly one third of the defense attorneys indicated they had clients who, were it not for the pandemic, not have accepted the offer.

Almost all attorneys in our sample believed that the fear of contracting COVID-19 has increased the willingness of their detained clients to plead guilty. However, they also thought non-detained clients, facing the prospect of an indefinite wait for trial, were more willing to plead guilty and some were accepting deals that were not as good as what they might have expected before the pandemic (i.e., before the pandemic, defendants might have held out for a better deal closer to their trial dates). Some defense attorneys also noted that misdemeanor cases were being given a lower priority for prosecution. In the attorneys' views, pleading guilty in these cases has been incentivized both by the various social impacts of having a minor case open indefinitely and by concerns that another arrest in that period of time could adversely impact outcomes in the original and subsequent cases. These social impacts of waiting are consistent with survey data from 500 defense attorneys that revealed a number of attorneys pre-COVID 
bargain in the "shadow of life circumstances" and not just potential trial outcomes (Wright, Roberts \& Wilkinson, 2020).

One factor we did not anticipate in our survey, but that came up in open-ended responses and interviews, was attorney concerns about the constitutionality of trials in jurisdictions where they were being held virtually or with other safety protocols in place that disrupt normal processes. For example, virtual hearings make it difficult to confer confidentially with a client and properly examine witnesses. From the attorneys' points of view, these impacts have further incentivized plea bargaining. The National Association of Criminal Defense Lawyers (NACDL) (2020) contemplated this predicament in a recent statement, advising courts that COVID-19 may place defendants in circumstances wherein they are "compelled to choose between the right to a speedy trial (potentially motivated by threat of contagion in detention), on one hand, and the right to confront prosecution witnesses and be physically present [to] participate in the trial, on the other" (p. 11).

Despite perceived impacts to the administration of justice, it is difficult to argue that court closures and the various other procedural and structural changes that have been implemented to limit the spread of the virus were not necessary. Nonetheless, it is reasonable to question whether prosecutors are capitalizing on defendants' fears of contracting COVID-19 and/or leveraging the long delays to trial to their advantage (Johnson, 2020). None of the defense attorneys in our sample reported witnessing unethical prosecutorial behavior. That said, our data do suggest that there is a great deal of variability with respect to prosecutorial behavior. As one attorney explained (Interview \#7), "It really depends on the prosecutor. There are some that are giving me amazing offers. But, I mean there are still those DAs, who, for example," — the attorney 
described a low-level case that would have likely been pleaded out prepandemic_— "He wouldn't even consider giving me a deal on that. And the guy was waiting it out in jail in the middle of COVID. So, I think it really depends on the prosecutor.” In other words, from the perspective of a number of attorneys we surveyed, the extent to which the pandemic-induced shifts in leverage threaten defendant autonomy is in large part dependent on the decisions of individual prosecutors.

Variability in prosecutor decisions can be attributable to many sources, both legal (e.g., case characteristics) and extralegal (e.g., race; Bandyopadhyay \& McCannon, 2014; Kutateladze et al., 2014; Wooldredge, 1989). Considering that the negative effects of COVID-19 on case backlogs are likely to continue for quite some time, additional research aimed at elucidating the underlying reasons for these differences would be fruitful. It is also important to note that our data reflect the experiences of defense attorneys, and largely those who had represented at least one detained client. While most attorneys addressed prosecutor behavior in their open-ended responses, we inevitably captured fewer data points from attorneys who had no detained clients.

\section{Validity of Guilty Pleas}

A valid guilty plea is one that is entered into knowingly, intelligently, and voluntarily (Boykin v. Alabama, 1969; Brady v. U.S., 1970). While the reports from the attorneys in our sample raise concerns about the validity of guilty pleas during the pandemic, legal scholars and social scientists have long questioned the adequacy of the procedural safeguards intended to ensure guilty pleas are constitutionally sound (Redlich, 2016). Interviews with individuals who have pleaded guilty reveal substantial deficits in basic legal knowledge relevant to their pleas (Redlich \& Summers, 2012: Zottoli \& Daftary-Kapur, 2019), despite the judges in their cases 
having found their decisions to be knowing and intelligent. In addition, defendants' access to evidence in their cases varies across jurisdictions (Turner \& Redlich, 2017; Zottoli et al., 2019), and defendants are often uninformed about a wide range of collateral consequences that may attach to their conviction (Bibas, 2011). Our data suggest that the procedural impacts of the pandemic have the potential to exacerbate existing system factors that put defendants at an informational disadvantage relative to the prosecutor.

As with the issues relating to informational deficits, concerns about the voluntariness of guilty pleas predate COVID-19 (Redlich \& Summer, 2012). According to Brady v. U.S. (1970), a voluntary plea is one that has not been induced by threats, misrepresentations or improper promises (e.g., bribes). One of the most common criticisms of plea bargaining is that the disparity between the plea offer and trial sentences is often so great that the plea offer is no more than a Hobson's choice (Dervan, 2012). From the perspective of the attorneys in this study, offers for time-served or probationary sentences in low-level cases (i.e., misdemeanors and low-level felonies) have increased during the pandemic. While we certainly acknowledge the benefits this confers to many defendants, we would be remiss not to acknowledge the potential for such offers to compel pleas from defendants who have a good chance of winning at trial or having charges dismissed.

These effects may be exacerbated when a plea sentence leads to immediate release from jail. Pretrial detention increases the likelihood that defendants will plead guilty under normal circumstances (Dobbie et al., 2018; Sacks \& Ackerman, 2012), and the majority of attorneys in our sample said that fear of contracting the virus has made getting out of jail an even higher priority for clients than it is normally. With long delays for trials, defendants are left with few 
options; in this context, the power of pretrial detention to induce guilty pleas is amplified. Our data suggest there is quite a bit of variability with respect to how prosecutors are using pretrial detention. Roughly a third of defense attorneys reported that prosecutors were using it less during the pandemic, suggesting a willingness to make concessions to minimize health risks to defendants. On the other hand, a few attorneys described situations that suggest some prosecutors may be capitalizing on detained defendants' circumstances. One response was particularly illustrative: "In many cases prosecutors have been making time served offers for people in jail, but simultaneously oppos[ing] defense requests for bail reductions [...]." From the perspective of social science, if not also the courts, such behavior calls into question the voluntariness of a defendant's decision to plead guilty.

Pretrial detention during the pandemic may effectively eliminate the option of rejecting a plea-for both guilty and innocent defendants (Maher, 2020). Similarly, the NACDL (2020) suggested that the shift in leverage to the prosecutor will contribute to "coercive plea bargaining" and "lead to wrongful convictions." While acknowledging that we have only the perspectives and experiences of a small number of attorneys from which to infer, our data do suggest these concerns are reasonable. Nearly one-third of our sample reported having had clients who claimed innocence but were willing to plead guilty for non-incarcerative sentences. Plea bargaining is associated with wrongful conviction in the U.S.; roughly $20 \%$ of documented exonerations involved defendants who pleaded guilty (National Registry of Exonerations, n.d.). In a recent survey of defense attorneys, $90 \%(n=148)$ of respondents reported having clients who pleaded guilty despite maintaining their innocence and 45\% $(n=74)$ reported having advised a client they believed to be innocent to plead guilty (Helm et al., 2018). While there may be rational 
reasons for pleading guilty when innocent, the legitimacy of any system of justice is called into question when the predominant mode of conviction is subject to error (Schulhofer, 1992).

Procedural safeguards to ensure that guilty pleas are valid and that innocent defendants are protected have proved insufficient (Dervan, 2012), and data from the current study suggest that the COVID-19 pandemic may pose additional risks for some defendants.

\section{Limitation and Future Directions}

Our survey collated the experiences of a small group of attorneys from across the U.S. who have represented clients during the pandemic. We make no claims as to the representativeness of our sample nor do we make any statistical inferences as to population parameters with respect to changes in guilty plea rates, prosecutor behaviors, or other outcomes we discuss. Rather, our goal with this project was to capture as broad a view of perspectives and potential issues as possible, across a wide range of jurisdictions, in order to provide a starting point for understanding the potential impacts of COVID-19 on plea-bargaining. This goal begs the question, why do we need a starting point for a pandemic that will eventually run its course? The downstream impacts of court closures such as backlogs in trial dates will surely outlast the life span of the virus (Johnson, 2020). But, perhaps more importantly, as it has done in other facets of society including the health care system and education, the pandemic has lain bare systemic problems within our already overburdened criminal justice system. The realities of globalization and climate change point to an increased likelihood for new pandemics in the future (Naicker, 2011). We can and should utilize this opportunity to identify system vulnerabilities and contemplate how we will mitigate these problems before we find ourselves 
face-to-face with another global crisis. It is in this light that we discuss the limitations of these data and suggest ideas for future work.

The primary limitations of our survey derive from sample non-representativeness and self-selection. These data were also the perceptions of defense attorneys - perceptions that may or may not objectively mirror actual changes related to the pandemic. We also did not include questions assessing attorney demographics (e.g., race, years of experience). At the same time, by virtue of the geographical diversity, we were able to highlight the extent of the variability in the impact on plea bargaining, as well as demonstrate similarities. Future studies should take a deeper dive into single jurisdictions, or conduct systematic comparisons across two or more jurisdictions, so as to generate quantitative estimates of the impacts on justice system outcomes and identify factors that contribute to any inter- or intra- jurisdictional differences.

We focused on defense attorneys and their perspectives regarding whether and how the pandemic has affected the plea process. We did not survey prosecutors and as such the perceptions of prosecutor behavior we observed are one-sided. Future investigations should attempt to capture the views of prosecutors. Research in related areas of criminal procedure have found differences in perceptions of defense attorneys and prosecutors (Turner \& Redlich, 2016), and this is likely true for how these two groups view the impact of the pandemic on the plea process. Similarly, although some defendants will have communicated COVID-19 fears with their attorneys, our reliance on defense attorney reports weakens assertions regarding the impact of COVID-19 on defendant plea decisions. This is an especially important caveat considering the difficulties in communication between client and counsel identified by attorneys in our sample. 
Our data also do not shed light on potential disparate impacts on Black, Indigenous and People of Color (BIPOC) defendants. In retrospect we wish we had inquired about the racial and ethnic composition of attorney caseloads and asked for their perspectives on disparate outcomes for BIPOC defendants. We urge future investigators to rectify our omission. BIPOC defendants are over-represented among those who receive custodial sentences and who are detained pretrial (Demuth, 2003). BIPOC individuals, especially Black Americans, have also been disproportionally affected by the pandemic (Tai, Shah, Doubeni, Sia, \& Wieland, 2020).

We narrowly focused on survey on plea bargaining and on the experiences of detained defendants in particular. There are many other questions worth asking about the pandemic's impact on the criminal justice system that investigators should pursue. These questions need not focus solely on court processes. For example (and as the attorneys in our sample also noted) many of the efforts by courts, prosecutors, and police to mitigate effects of the virus - such as lower arrest rates, increased dismissals and significant reductions in the use of pretrial detention for certain charge categories (COVID-19 Sparks 'Unprecedented' Pretrial Reforms, Survey Shows, 2020) — each has implications for reduction of the criminal justice footprint and alleviation of problems associated with mass incarceration. Systematic follow-up studies on the impacts of these policies in terms of recidivism and community safety would be informative for policymakers.

\section{Conclusion}

COVID-19 is having a substantial impact on the criminal justice system in the U.S. From the perspective of the defense attorneys in our sample, the extent to which attorneys are able to access and advise their clients has been substantially impacted and the leverage in guilty plea 
negotiation has shifted further to the prosecutor even though prosecutors seem to be offering more lenient deals during COVID-19. On the whole, defense attorneys perceived these impacts as disadvantaging their clients, particularly those who are detained, though there was quite a bit of variability in the experiences reported. To our knowledge, this study is the first to report on the experiences of practicing attorneys during the pandemic. We hope it will serve as a catalyst for more systematic research that will lead to improved criminal justice outcomes for defendants and their communities. 


\section{References}

Baldwin, J. M., Eassey, J. M., \& Brooke, E. J. (2020). Court Operations during the COVID-19 Pandemic. Journal of American Criminal Justice. https://doi.org/10.1007/s12103-020-09553-1

Bibas, S. (2011). Regulating the Plea-Bargaining Market: From Caveat Emptor to Consumer Protection. California Law Review, 99. Retrieved from https://heinonline.org/HOL/Page?handle=hein.journals/calr99\&id=1125\&div=\&collection= Boykin v. Alabama, 395 US 238 (1969)

Brady v. United States, 397 U.S. 742 (1970)

Caldwell, H. M. (2011). Coercive plea bargaining: the unrecognized scourge of the justice system. Catholic University Law Review, 61.

Cannon, R. (2020). Sick Deal: Injustice and Plea Bargaining During COVID-19. Journal of Criminal Law and Criminology. http://dx.doi.org/10.2139/ssrn.3632508

Council on Criminal Justice. (2020, April 17). Facing COVID-19 in the Courts (Webinar). Retrieved from https://justiceroundtable.org/event/council-on-criminal-justice-facing-covid-19-in-the-cou rts/

COVID-19 Sparks 'Unprecedented' Pretrial Reforms, Survey Shows. Arnold Ventures. Retrieved from https://www.arnoldventures.org/stories/covid-19-sparks-unprecedented-pretrial-reforms-s urvey-shows/

Dobbie, W., Goldin, J., \& Yang, C. S. (2018). The effects of pretrial detention on conviction, 
Future crime, and employment: Evidence from randomly assigned judges. American Economic Review, 108(2), 201-40.

Demuth, S. (2003). Racial and ethnic differences in pretrial release decisions and outcomes: A comparison of Hispanic, black, and white felony arrestees. Criminology, 41(3), 873-908. https://doi.org/10.1111/j.1745-9125.2003.tb01007.x

Dervan, L. E. (2012). Bargained justice: Plea-bargaining's innocence problem and the Brady safety-valve. Utah Law Review, 51, 51-97.

Devers, L. (2011). Plea and Charge Bargaining: Research Summary. Retrieved from https://bja.ojp.gov/sites/g/files/xyckuh186/files/media/document/PleaBargainingResearch $\underline{\text { Summary.pdf }}$

Edkins, V. A., \& Dervan, L. E. (2018). Freedom now or a future later: Pitting the lasting implications of collateral consequences against pretrial detention in decisions to plead guilty. Psychology, Public Policy, and Law, 24(2), 204-215. https://doi.org/10.1037/law0000159

Euvrard, E., \& Leclerc, C. (2017). Pre-trial detention and guilty pleas: Inducement or coercion? Punishment \& Society, 19(5), 525-542. https://doi.org/10.1177/1462474516670153

Farole, D. J. \& Langton, L. (2010). A national assessment of public defender office caseloads. Judicature, 94(2), 87-90.

Feuer, A., Hong, N., Weiser, B., \& Ransom, J. (2020, June 22). N.Y.'s Legal Limbo: Pandemic Creates Backlog of 39,200 Criminal Cases. The New York Times. https://www.nytimes.com/2020/06/22/nyregion/coronavirus-new-york-courts.html 
Gideon v. Wainwright, 372 U.S. 335 (1963)

Howe, A. (2020). Courtroom access: Faced with a pandemic, the Supreme Court pivots. https://www.scotusblog.com/2020/04/courtroom-access-faced-with-a-pandemic-the-supre $\underline{\text { me-court-pivots/ }}$

Johnson, T. (2020). Crisis and Coercive Pleas. Journal of Criminal Law and Criminology. http://dx.doi.org/10.2139/ssrn.3632052

Jouvenal, J. (2020, August 12). Justice by Zoom: Frozen video, a cat — and finally a verdict. The Washington Post. https://www.washingtonpost.com/local/legal-issues/justice-by-zoom-frozen-video-a-cat-and-finally-a-verdict/2020/08/12/3e073c56-dbd3-11ea-8051-d5f887d73381 story.html

Lafler v. Cooper, 566 U.S. 156 (2012)

Lefstein, N., \& Spangenberg, R. L. (2009). Justice Denied: America's Continuing Neglect of our Constitutional Right to Counsel Report of the National Right to Counsel Committee. Washington, D.C.: The Constitution Project.

Maher, T. (2020, May 19). Plea Bargaining in the Shadow of COVID-19. Duke Law Center for Science and Justice Blog. https://sites.law.duke.edu/csj-blog/2020/05/19/plea-bargaining-in-the-shadow-of-covid-1 9/

McCoy, C. (2005). Plea bargaining as coercion: The trial penalty and plea bargaining reform. Criminal Law Quarterly, 50, 67-107.

McCough. M. (2011). Indigent defense: International perspectives and research needs. National Institute of Justice Journal, 268, 36-39. 
National Association of Criminal Defense Lawyers (2020). Criminal Court Reopening and Public Health in the COVID-19 Era. Retrieved from https://www.nacdl.org/Document/CriminalCourtReopeningAndCOVID-19

Naicker, P. R. (2011). The impact of climate change and other factors on zoonotic diseases. Archives of Clinical Microbiology, 2(2).

Peterson, N. (2019). Do Detainees Plead Guilty Faster? A Survival Analysis of Pretrial Detention and the Timing of Guilty Pleas. Criminal Justice Policy Review, 1-21. DOI: $10.1177 / 0887403419838020$

Redlich, A. D. (2016). The validity of pleading guilty. In Advances in psychology and law (pp. 126). Springer, Cham.

Redlich, A. D., \& Summers, A. (2012). Voluntary, knowing, and intelligent pleas: Understanding the plea inquiry. Psychology, Public Policy, and Law, 18(4), 626.

Roth, J. (2020, October 10). The Constitution is on Pause in America's Courtrooms. The Atlantic.https://www.theatlantic.com/ideas/archive/2020/10/constitution-pause-americascourtrooms $/ 616633 /$

Sacks, M., \& Ackerman, A. R. (2012). Pretrial detention and guilty pleas: if they cannot afford bail they must be guilty. Criminal Justice Studies, 25(3), 265-278.

Saloner, B., Parish, K., Ward, J. A., DiLaura, G., \& Dolovich, S. (2020). COVID-19 Cases and Deaths in Federal and State Prisons. The Journal of American Medical Association, 324(6), 602-603. doi:10.1001/jama.2020.12528

Schulhofer, S. J. (1992). Plea bargaining as disaster. The Yale Law Journal, 101(8), 1979-2009. Strickland v. Washington, 466 U.S. 668, 104 S. Ct. 2052, 80 L. Ed. 2 d 674 (1984) 
Stuart, C. (2020, September 16). Court Backlog Builds During Ongoing COVID-19 Pandemic. NBC News. https://www.nbcconnecticut.com/news/coronavirus/court-backlog-builds-during-ongoing$\underline{\text { covid-19-pandemic/2333462/ }}$

Tai, D. B. G., Shah, A., Doubeni, C. A., Sia, I. G., \& Wieland, M. L. (2020). The disproportionate impact of COVID-19 on racial and ethnic minorities in the United States. Clinical Infectious Diseases.

The National Registry of Exonerations (n.d.). Retrieved from http://www.law.umich.edu/special/exoneration/Pages/about.aspx

Turner, J. I. (2020). Remote Criminal Justice. Texas Tech Law Review (Forthcoming 2021), Available at SSRN: https://ssrn.com/abstract $=3699045$ or http://dx.doi.org/10.2139/ssrn.3699045

Turner, J. I., \& Redlich, A. D. (2016). Two models of pre-plea discovery in criminal cases: An empirical comparison. Wash. \& Lee L. Rev., 73, 285.

Wright, R. F., Roberts, J., \& Wilkinson, B. (2020). The shadow bargainers. Cardoza Law Review. WLC Research Paper No. 2020-13, Available at SSRN: https://ssrn.com/abstract=3577322

Zottoli, T. M. \& Daftary-Kapur, T. (2019). Guilty pleas of youths and adults: Differences in legal knowledge and decision making. Law and Human Behavior, 43(2), 166.

Zottoli, T. M., Daftary-Kapur, T., Edkins, V. A., Redlich, A. D., King, C. M., Dervan, L. E., \& Tahan, E. (2019). State of the States: A survey of statutory law, regulations and court 
rules pertaining to guilty pleas across the United States. Behavioral Sciences \& the Law, 37(4), 388-434.

Zottoli, T. M., Daftary-Kapur, T., Winters, G. M., \& Hogan, C. (2016). Plea discounts, time pressures, and false-guilty pleas in youth and adults who pleaded guilty to felonies in New York City. Psychology, Public Policy, and Law, 22(3), 250. 
Table 1. Defense Attorney Respondents by Region and State

\begin{tabular}{lcc}
\hline Region/State & Frequenc & Percen \\
West & $\mathrm{y}$ & $\mathrm{t}$ \\
California & 4 & 4.30 \\
New Mexico & 5 & 5.38 \\
Oregon & 10 & 10.75 \\
Wyoming & 2 & 2.15 \\
Washington & 7 & 7.53 \\
Midwest & & \\
Illinois & 4 & 4.30 \\
Kansas & 3 & 3.23 \\
Michigan & 5 & 5.38 \\
Wisconsin & 8 & 8.60 \\
South & & \\
Florida & 8 & 8.60 \\
Georgia & 6 & 6.45 \\
North Carolina & 4 & 4.30 \\
Oklahoma & 4 & 4.30 \\
Northeast & & \\
Maryland & 4 & 4.30 \\
New Hampshire & 2 & 2.15 \\
New Jersey & 4 & 4.30 \\
New York & 8 & 8.60 \\
Pennsylvania & 3 & 3.23 \\
Massachusetts & 2 & 2.15 \\
\hline & & \\
\hline & &
\end{tabular}


Table 2. Average Scores on Scale Items (Survey Responses)

\begin{tabular}{|c|c|c|c|c|}
\hline Item & $n$ & $M$ & $\mathrm{SD}$ & Mode \\
\hline I have changed how I am advising my clients during the COVID-19 pandemic & 93 & 64.56 & 33.05 & 100 \\
\hline My access to clients has been impacted as a result of COVID-19 & 93 & 84.12 & 26.62 & 100 \\
\hline Prosecutors are dismissing cases at a greater rate during COVID-19 & 68 & 34.82 & 33.62 & 0 \\
\hline Prosecutors are utilizing pre-trial detention less frequently during COVID-19 & 68 & 44.37 & 36.08 & 50 \\
\hline
\end{tabular}

Note. All items were rated on a slider scale of 0-100, with 0 indicating "strongly disagree" and 100 indicating "strongly agree". 
Table 3. Factors Affecting Plea-Bargaining and Decisions (Qualitative Interviews): Categories, Percentage Referenced, and Example Responses

\begin{tabular}{|c|c|c|}
\hline Category- Definition & $\begin{array}{c}\text { Percentag } \\
\text { e (n) }\end{array}$ & Examples \\
\hline \multicolumn{3}{|c|}{ Impact of COVID-19 on Court Procedures and Related Processes } \\
\hline $\begin{array}{l}\text { Client_access- Accessing clients } \\
\text { challenging during COVID }\end{array}$ & $\begin{array}{l}23.08 \% \\
(3)\end{array}$ & $\begin{array}{l}\text { "My concern is my in-custody clients and being able to contact my in-custody clients has been } \\
\text { so severely impacted."- Interview \#4 }\end{array}$ \\
\hline $\begin{array}{l}\text { Technology- Issues for defendants } \\
\text { with barriers in technology } \\
\text { access (e.g., no internet, } \\
\text { computer) }\end{array}$ & $\begin{array}{l}23.08 \% \\
(3)\end{array}$ & $\begin{array}{l}\text { "My clients don't have computers, they don't have the internet, they don't have phones and so } \\
\text { they're just like all set up a zoom meeting just use your cell phone and call in and it's like none } \\
\text { of my clients have that ability. And the courts have taken almost no basically absolutely no } \\
\text { recognition of that so they are weirdly throwing people in jail because they don't have the } \\
\text { ability to do anything with zoom."- Interview \#5 }\end{array}$ \\
\hline $\begin{array}{l}\text { Alternatives- Lack of options for } \\
\text { community intervention has } \\
\text { impacted decisions (e.g., } \\
\text { community service, evals) }\end{array}$ & $\begin{array}{l}23.08 \% \\
(3)\end{array}$ & $\begin{array}{l}\text { "There's no community service available so we keep getting called up week after week your } \\
\text { client has another community service. I'm like where would you like them to do their } \\
\text { community service, they are like we don't know but they need to do it so the judges and } \\
\text { probation you know they're not really recognizing that reality."- Interview \#5 }\end{array}$ \\
\hline $\begin{array}{l}\text { Virtual_proceedings- Virtual } \\
\text { proceedings have reduced the } \\
\text { quality of representation }\end{array}$ & $\begin{array}{l}23.08 \% \\
(3)\end{array}$ & $\begin{array}{l}\text { "I do think that some of that like speedy trial concerns, confrontation concerns, I absolutely } \\
\text { could see how that could usher someone closer to saying well like if I don't feel like I can get a } \\
\text { fair trial than I need [to] enter a plea..."- Interview \#3 }\end{array}$ \\
\hline $\begin{array}{l}\text { Jail_practices-COVID jail } \\
\text { practices influencing client } \\
\text { decisions }\end{array}$ & $\begin{array}{l}15.38 \% \\
(2)\end{array}$ & $\begin{array}{l}\text { "We have a condition of the quarantine process, that if your client wants to appear in court, } \\
\text { they will be quarantined for } 21 \text { days, so in the hole for } 21 \text { days. So they have to make a } \\
\text { decision if they want to appear in court for an important hearing or not, make a choice } \\
\text { between not appearing or being in solitary confinement."- Interview \#1 }\end{array}$ \\
\hline $\begin{array}{l}\text { Virtual_constitutional- } \\
\text { Constitutional deficiencies in } \\
\text { virtual proceedings }\end{array}$ & $\begin{array}{l}38.46 \% \\
\quad(5)\end{array}$ & $\begin{array}{l}\text { "If a client wants to come back later and say I was coerced, we don't want to solve that. If } \\
\text { anything, our plea deals have become more fast and furious because judges are low on time. } \\
\text { Plea deals aren’t even being signed by clients...pleas are becoming less formalized." - } \\
\text { Interview \#13 }\end{array}$ \\
\hline
\end{tabular}


Impact of COVID-19 on Plea Bargaining and Prosecutorial Behavior

\begin{tabular}{l}
\hline Leverage_D- Leverage in plea \\
negotiations has shifted toward \\
the defendant \\
Leverage_P-Leverage in plea \\
negotiations has shifted toward \\
the prosecutor \\
Plea_better-Plea offers better \\
during COVID
\end{tabular}

Plea_worse- Plea offers worse during COVID

Pros_unwilling-Prosecutors unwilling to bargain during COVID

Pros dismissals- Increase in dismissals by prosecutors during COVID

Bargain_time-_Bargain time has increased during COVID
$38.46 \%$ "Yes I do I think leverage on you know the defendants end is increasing as time goes by every

(5) day, every week that goes by that we don't have a jury.”- Interview \#3

$46.15 \% \quad$ "...In some cases in which I believe they would have been misdemeanor offers, prosecutors (6) have been wanting them to plead to every charge, and get a felony conviction. And there is no leverage, there is no leverage to say, like 6 months ago I would have said fine we will have 5 trials, and no prosecutor wants to do that so they will plead down, but now we don't have that leverage."- Interview \#1

$38.46 \%$ "Some of them [prosecutors] are not quite so free with using COVID as an excuse to lower (5) plea offers and others with more experience are- we've got a tsunami of backlogs coming our way and we're going to have to deal with this- so they are doing that."- Interview \#9

$38.46 \%$ "The state is making offers they're not what I would consider good offers and in normal times (5) I would advise clients to push forward to a trial but then if you're just held in custody forever, my clients are much more likely to take a plea that's not favorable to get them out of custody."'- Interview \#4

46.15\% "I mean oftentimes their plea offers are just like "we can plead straight up their to the charge" (6) and I'm like that's actually not an offer like I could do that any day, we could literally go in front of the court and plead guilty any time we wanted so that's not an offer and I'm sending out emails and getting no responses on them."'- Interview \#4

23.08\% "Lots of dismissals in the misdemeanor range...things like second-degree trespass, possession of less than half an ounce of marijuana, possession of marijuana drug paraphernalia, a lot of those were getting dismissals before the even the court date, the DA's just going this isn't even worth the time..."- Interview \#9

$15.38 \% \quad$ "There's no like speedy trial, the Supreme Court has essentially said speedy trial is paused (2) during the pandemic and we're just sitting, waiting, and people are rotting in custody."Interview \#4 
Waivers- Additional waivers because of COVID
7.69\% "For misdemeanor cases, waivers of appearance in their entirety, where a client will execute a waiver that says your attorney may enter a plea on your behalf within this range, and negotiate as necessary and then enter that plea and inform you of what the results are."- Interview \#9

Impact of COVID-19 on Defendant Decision-making

\footnotetext{
COVID jail- Defendant concern about catching COVID in jail for those who were detained
COVID_out- Desire to accept a plea deal because of COVID, even though they weren't detained
Jury_trial- Lack of jury trials pressured defendants to take a plea; reference speedy trial

Innocence- At least one client who was innocent and plead or was interested in pleading guilty due to COVID related issues

Plead_COVID-Pleading due to COVID related conditions, when in normal conditions they would have held out

Timeline- Pleading because of uncertainty of timeline of case/hearings
}

"My clients who are in jail who already have health conditions going on have, I've had a number of them mention to me a real discomfort with [being] in custody and an increased willingness to do whatever it takes to get out..."- Interview \#6
15.38\% "And not just the people who are in custody. I have had clients who are saying I need to get past this, there is so much else going on that is chaotic, I need to get past this case, I don't want to have to keep coming into a court system where I am not feeling safe..."- Interview $\# 13$

$84.62 \% \quad$ “...Like the huge time difference between they're charged and when they have a trial is really (11) leading people to look at pleas like their only option, I think it's really suffocating to some extent..."- Interview \#10

$38.46 \%$ "I have another person who is charged with manslaughter who is actually innocent and that person has been waiting for a year and he is getting so desperate he is telling me he wants to plead to something..."- Interview \#1

$46.15 \% \quad$ "In my own practice my own clients I can think of, at least 2 or 3 have pled guilty to things (6) that they could probably, in another time, would not have pled guilty to, just to get out of jail, just to resolve a case, because my answer to them right now is, when they ask, when are things happening, and my answer to them, is always I don't know."- Interview \#1

$46.15 \% \quad$ "I guess it decreases the level of suffering when you know you are going to court and for me (6) not being able to go... and tell my clients "hey we are going to court on this date" got one right now that wants to know his court date is gonna be."- Interview \#3 
Case_backlog-Case backlog influencing plea-bargaining (for attorneys)
53.85\% "The plea recommendations and the results that we get you know the likelihood of dismissals will be even greater as the prosecutor start to realize this [lack of jury trials and case backlog]...I know that it is truly speculative on my end but it's just common sense um experiencing math and simple economics, law of scarcity. We were already behind."- 
